\title{
Cognitive and Psychopathological Profile on Catholic Nuns in Puerto Rico: An Exploratory Study
}

\author{
Perfil Cognitivo y Psicopatológico de Monjas Católicas en Puerto Rico: Un \\ Estudio Exploratorio
}

\author{
José R. Rodríguez-Gómez ${ }^{1 *}$, \& Stephanie M. Vega-Molina ${ }^{2}$ \\ 1 Carlos Albizu University, San Juan Campus, Puerto Rico. (D) https://orcid.org/0000-0001-9544-6002 \\ 2 Carlos Albizu University, San Juan Campus, Puerto Rico. (D) https://orcid.org/0000-0001-7144-3296 \\ * Correspondencia: jrodriguez@albizu.edu. P.O. Box 9023711, San Juan, P.R. 00902
}

Recibido: 17 mayo 2020 | Aceptado: 8 junio 2020 | Publicado: 15 julio 2020

WWW.REVISTACARIBENADEPSICOLOGIA.COM

\section{Citar como:}

Rodríguez-Gómez, J. R., \& Vega-Molina, S. M. (2020). Cognitive and psychopathological profile on catholic nuns in Puerto Rico: An exploratory study. Revista Caribeña de Psicología, 4(2), 88-97.

https://doi.org/10.37226/rcp.v4i2.4123

\begin{abstract}
The vocation of Catholic nun has spread virtually throughout the world for hundreds of years. The purpose of this pioneer nun study in Puerto Rico was to generate a comprehensive cognitive and psychopathological profile in a particular sample that usually shares a similar environment and lifestyle. Even though nuns have been studied in the United States and other parts of the world, no known study conducted with Puerto Rican nuns has been found in local academic databases explored in the last ten years using the subject keywords (i.e., Puerto Rican Nuns) in data search. The sample consisted of 25 female catholic nuns, residents in Puerto Rico, with a median age of 60.96 years old. A Non-probability sampling method was utilized to retrieve the participants. The following instruments were used: Beck Anxiety Inventory (BAI), Beck Depression Inventory (BDI-II), Beck Hopelessness Inventory (BHS), Symptom Checklist 90-R, and Folstein Mini-Mental State Examination (MMSE). Significant findings among BDI-II results $(t=2.377, p<.05)$, BHS results $(t=34.671, p<.05)$ and Mini-mental examination $(t=16.613, p<.05)$. An ANOVA was conducted to evaluate significant differences among the subscales of the 90-Symptom Checklist; significant differences were found. Results suggested that symptoms of psychopathology are present predominantly at a minimal level. However, mild to moderate results were also found. Nuns in the sample showed high cognitive functioning and were capable of performing the tasks assigned. Future research may include a bigger sample and comparisons among cloistered and apostolic nuns. A mixed methodology is suggested.
\end{abstract}

Palabras Claves: Puerto Ricans nuns; psychopathology; nun mental health; Puerto Rico

\section{RESUMEN}

La vocación de la monja católica se ha extendido virtualmente por todo el mundo durante cientos de años. El propósito de este estudio de monjas pioneras en Puerto Rico es generar un perfil cognitivo y psicopatológico integral en una muestra particular que generalmente comparte un ambiente y estilo de vida similar. A pesar de que las monjas se han estudiado en los Estados Unidos y en otras partes del mundo, no se ha encontrado ningún estudio 
conocido realizado con monjas puertorriqueñas en bases de datos académicas locales exploradas en los últimos diez años utilizando las palabras clave del tema (es decir, monjas puertorriqueñas) en la búsqueda de datos. La muestra consta de 25 monjas católicas, residentes en Puerto Rico, con una edad promedio de 60.96 años (DE = 17.594; RANGO = 61). Se utilizó un método de muestreo no probabilístico para recuperar a los participantes. Se utilizaron los siguientes instrumentos: Beck Anxiety Inventory (BAI), Beck Depression Inventory (BDI-II), Beck Hopelessness Inventory (BHS), Symptom Checklist 90-R y Folstein Mini-Mental State Examination (MMSE). Hallazgos significativos entre los resultados de BDI-II $(t=2.377, p<.05)$, resultados de BHS $(t=34.671, p<.05)$ y Mini examen mental $(t=16.613, p<.05)$. Se realizó un ANOVA para evaluar diferencias significativas entre las subescalas de la Lista de verificación de los 90 síntomas. Los resultados sugieren que los síntomas de la psicopatología están presentes predominantemente en un nivel mínimo. Sin embargo, también se encontraron resultados de leve a moderados. Las monjas de la muestra mostraron un alto funcionamiento cognitivo y fueron capaces de realizar las tareas asignadas. La investigación futura puede incluir una muestra más grande y comparaciones entre monjas enclaustradas y apostólicas. Se sugiere una metodología mixta.

Keywords: monjas puertorriqueñas; psicopatología; salud mental de monjas; Puerto Rico

\section{INTRODUCTION}

The place of women in a religious setting is complicated and has many different facets, depending on the time, place, and a myriad of socio-cultural details belonging to a specific geographic region. Among the many diverse groups, focusing on those minorities, Catholic nuns are a particular group of women to study. "As a particular group of women living a specific way of life within the broader context of religion, catholic nuns have largely been under-researched in the social sciences" (Brock, 2013).

The vocation of Catholic nun has spread virtually throughout the world for hundreds of years. Out of this drift, several orders have been established, which have particular characteristics and responsibilities. In most cases, these are influenced by a saint, holy person, or by a specific set of cultural characteristics or spiritually significant geographic locations. The nun believes that one must take responsibility for one's own life and the spiritual practice of others in the church. As a result, the church has been instrumental in shaping the individual roles of these women and has implemented a subjective discipline based on clerical and canonical law members of the church with their aid through them (Rose, 1996).

Religious life has always been understood by the Catholic Church to be a total consecration of oneself to God. The term "consecrated" meaning reserved to God by choosing to live life according to the vows of poverty, chastity, and obedience. Their lifestyle choice may not be according to the world's schemes, but to live in holiness and as part of a deep divine mission. Various Christian orders of Nuns abide by this calling.

\section{Justification}

The purpose of this pioneer nun study in Puerto Rico is to generate a primary comprehensive psychopathological profile of this particular segment of the Puerto Rican population that usually shares a similar environment and lifestyle. Although nuns have been studied in the United States and other parts of the world, no known study conducted with Puerto Rican nuns has been found in local academic databases in the last ten years. The enduring Catholic roots and its presence in Hispanic and Puerto Rican history and culture still significantly influence Christian values held and taught today on the island of Puerto Rico. Thus, the interest in studying the nun population in Puerto Rico, and learning about their mental health status can help understand basic psychopathology that can affect their status. This study aims to take the first steps to describe and explore some components of psychological characteristics and cognitive functioning, considering the nun lifestyle and physical environment.

\section{Objectives}

The study's objective is to develop an initial cognitive and psychopathological profile of mental health among different nun congregations in Puerto Rico. This profile will be obtained by comparing the results of four areas of psychopathology and cognitive abilities: depression, anxiety, hopelessness, and cognitive impairment/neurological deterioration. Five inventories will be used as instruments to gather 
the participant's information: The Beck Depression Inventory (BDI-II), The Beck Anxiety Inventory (BAI), and The Beck Hopelessness Scale (BHS). The "Revised Symptom Checklist- 90" will also be administered to explore more extensively symptoms related to other possible mental health disorders. The Folstein Mini-Mental Exam will be used to measure possible cognitive impairment/neurological deterioration. The results obtained by the measured levels of depression, anxiety, and hopelessness and any other significant findings will be described for the participating nun sample.

\section{Hypothesis}

The null hypothesis (H0) states that no significant differences at a statistical level $(p<.05)$ will be found among the depression, anxiety, and hopelessness levels gathered from the nuns. This first hypothesis (H1) states that no significant differences at a statistical level $(p<.05)$ will be found in the 90-Symptom Checklist results as related to the four areas under study. The second hypothesis (H2) states that no significant differences in cognitive impairment/neurological deterioration will be found in the Folstein Mini-Mental State Exam results related to the four areas under study.

\section{METHOD}

\section{Participants}

The population consisted of 25 Catholic Nuns of an identifiable, officially approved, and recognized religious congregation in Puerto Rico. The subjects above had to be at least 21 years of age and residing in Puerto Rico. A Non-Probability Sampling method was used to contact, orient, and consent the participants in the study. The inquiry was made via telephone calls and scheduled in-person visits. Contact information was obtained through a variety of accessible sources of information such as websites, mutual acquaintances, geographical proximity, or consulting the phone book to identify congregations. The inclusion criteria included: (1) participants are to be nuns of an identifiable, officially approved and recognized congregation, (2) must be older than 21 years of age, and (3) residing in Puerto Rico.

Given the nature and requirements of the tests to be administered, all participating nuns must be able to hear and read if they are to complete all instru- mentation. The sample was composed of 25 nuns, 11 from rural areas, and 14 from northern metropolitan areas in Puerto Rico. The municipal districts among their actual residency include San Juan (3), Trujillo Alto (5), Caguas (5), Bayamón (1), Juncos (2), and Humacao (9). The sample was heterogeneous in age $(\bar{x}=$ 60.96 years), which covered a range from 22 to 85 years. In terms of education, one had only completed Junior High School, three completed High School, eleven had an Associate or Bachelor's degree, and ten had either a Master's or Doctor's degree. Four of them were from a cloistered congregation, whereas the 21 remaining followed an apostolic way of life (Table 1).

\section{Table 1}

Socio-Demographic Variables in the Nun Sample.

\begin{tabular}{ll}
\hline Gender & 25 Women \\
Mean Age & 60.96 years \\
Prevalent Civil Status & Single \\
Prevalent Education (Bimodal) & Sub-graduate \\
Prevalent Religion Belief & Roman-Catholic \\
Prevalent Residency Area & Metropolitan Area \\
Prevalent Congregational Lifestyle & Apostolic Life \\
\hline
\end{tabular}

\section{Measures}

Symptom Checklist 90-R (SCL-90R). The SCL$90 \mathrm{R}$ is a multidimensional self-administered questionnaire developed by Derogatis (1997). It consists of 90 items, designed initially to assess the degree of discomfort in psychiatric patients and non-clinical subjects. Psychological distress is measured in nine primary dimensions (somatization, obsession-compulsion, interpersonal sensitivity, depression, anxiety, hostility, phobic anxiety, paranoid ideation, and psychoticism). From these dimensions, three global indexes of distress are obtained, which indicate different aspects of the general psychopathological suffering. The first is the Global Index (GSI, Global Symptom Index), which indicates the degree of malaise and indiscriminate intensity secondary to psychic and psychosomatic global suffering. According to Derogatis (1997), Global Severity Index (GSI) is the best indicator of distress and should be used whenever a single index assessment is needed. The second index is the total of positive symptoms (PST), also called Total Positive Responses. Finally, the third index is the rate of anxiety positive symptoms (PSDI) that relate global suffering with the number of symptoms and is, therefore, an indicator of the intensity measured by 
symptomatic. The primary symptom dimensions provide a profile of the areas of psychopathology, including discrete symptoms. The estimated time for administration is between 40 minutes to 55 minutes.

Beck Depression Inventory (BDI-II). The BDI-II is a self-administered 21-item instrument used to assess the severity of depressive symptoms. According to Beck (1996), reagents evaluate affective, cognitive, motor, and somatic symptoms. For each item, the participant can select from four possible alternatives ranging from 0 to 3 depending on the severity of the symptom. The total score is calculated by the sum of all items. According to this version, the score can be classified as follow: (0-13) Minimal, (14-19) Mild, (2028) Moderate, and (29-63) Severe. The estimated time for administration is approximately ten minutes.

Beck Anxiety Inventory (BAI). This inventory assesses the severity of anxiety in patients. BAI consists of 21 items describing states of anxiety on a scale of 0 to 3 , where 0 is a no symptom, and 3 is a severe level. The score ranges from $0-7$, which is considered a minimum state of anxiety; 8-15 indicates a mild state of anxiety; $16-25$ reflect a moderate state of anxiety, and scores of 26- 63 indicate a severe state of anxiety. The administration time of inventory is approximately 20 minutes.

Beck Hopelessness Inventory (BHS). The BHS consists of 24 items that measure negative attitudes related to the future. Each item is answered with a "true" or "false." The total amount comprises a range of 0 to 20, indicating the degree of hopelessness. The estimated time of administration is five to ten minutes.

Mini-Mental State Examination (MMSE). The MMSE measures the severity of cognitive impairment and consists of eleven items. The maximum total score is 30 points; from 21 to 30 points suggests a cognitive disability where severity is mild; ten to 20 points suggest moderate severity of the cognitive disability and 0 to nine suggest severe cognitive impairment. The time of administration is three minutes.

\section{Procedures}

Nuns were contacted by researchers via telephone and were given an extensive explanation regarding the study. After contacting the nuns, group meetings were scheduled at the convent or residency. For those who wished to participate, the informed consent was discussed. This information was transmitted in a nontheoretical and straightforward language. It was explained to the participants that the purpose of the study was to develop a profile. It was also explained that participation in the study was voluntary and that initial refusal or withdrawing from the study would incur no penalties. Participants were informed of the confidentiality regarding their participation and provided a window of ten minutes for answering all questions.

\section{RESULTS}

Participant scores on the Beck Anxiety Inventory (BAI) range as follow: (0-7) None or minimal, (8-15) Mild, (16-25) Moderate, and (26-63) Severe. Descriptive statistics yielded a range between 0 and 19, with a mean score for the 25 participants indicating the minimal presence of anxiety symptoms $(M=5.28)$. Frequencies indicate that 19 of the 25 participating nuns were in the minimal range, whereas four were found mild, and two were found moderate. Descriptive statistical analysis indicates that in terms of the severity of the scale, the participants did not report a significant number of distressing symptoms $(t=1.732$, $p>$.05). See Table 2 .

Table 2

T-test for Severity levels among the BAI, BDI-II, BHS and MiniMental Scales.

\begin{tabular}{ccccc}
\hline Inventories & $t$ & $p$ & \multicolumn{2}{c}{$\begin{array}{c}\text { 95\% Confidence In- } \\
\text { terval of the Differ- } \\
\text { ence }\end{array}$} \\
\hline Anxiety & 1.732 & .096 & -.0383 & .4383 \\
Depression & 2.377 & .026 & .0474 & .6726 \\
Hopelessness & 34.671 & .000 & 1.8057 & 2.0343 \\
Mini-Mental Status & 16.613 & .000 & .8057 & 1.0343 \\
\hline
\end{tabular}

Participant scores on the Beck Depression Inventory (BDI-II) range as follow: (0-3) Minimal, (14-19) Mild, (20-28) Moderate, and (29-63) Severe. Descriptive statistics yielded a range between 0 and 30 with a mean score for the 25 participants indicating a minimal presence of depressive symptoms $(M=7.12)$. Frequencies indicate that 19 participants show minimal depressive symptoms, four were found mild, and two were found moderate. However, descriptive statistical analysis indicates that in terms of the severity of the scale, the participants did report a significant number of distressing symptoms $(t=2.377, p<.05)$. See Table 2. 
Participant scores on the Beck Hopelessness Scale (BHS) range as follow: (0-3) None or minimal, (4-8) Mild, (9-14) Moderate, and (15) Severe. Descriptive statistics yielded a mean score for the 25 participants indicating a moderate presence of hopelessness symptoms $(M=10.52)$. Frequencies indicate that two participants show minimal or no hopelessness symptoms and 23 with moderate symptoms. The concept of hopelessness refers to measuring the need for affection and well-being in terms of the future. Thus, descriptive statistical analysis indicated that in terms of the severity of the scale, the participants did report a significant number of distressing symptoms $(t=$ 34.671, $p<.05)$. See Table 3.

The Mini-Mental State Examination (MMSE), Folstein Version measure areas such as orientation, registration, attention, recall, and language. The dispersion among the scores is from 30 to 23 . A score of 23 or less indicates cognitive impairment; thus, a score of 23 or more indicates high cognitive functioning. Results indicate a mean score for the 25 participants, indicating high cognitive functioning $(M=27.55)$. Frequencies indicate that 23 women resulted in having high cognitive functioning, whereas only two were found to have cognitive impairment. However, statistical analysis in terms of the severity of the scale showed significant differences $(t=16.613, p<.05)$.

Descriptive statistics and frequency analysis were carried out for the SCL-90-R, which included the cumulative and scores for the nine subscales that make up the Global Severity Index (GSI). This particular score (GSI) provides an overall assessment of psychopathology and indices of levels of symptomatology and psychological Distress (Derogatis, 1994). Findings demonstrate that 20 participants were classified as having an absence of distressing symptoms in the Phobic Anxiety and Psychoticism Dimensions. Twenty participants were classified as having an absence of distressing symptoms in the Anxiety and Hostility Dimension. Consequently, 18 participants were classified as having an absence of distressing symptoms in the Depression Scale. Also, 17 participants were classified as having an absence of distressing symptoms in the Interpersonal Sensitivity, Paranoid Ideation, and the Global Severity Index.

Moreover, sixteen participants were classified as having an absence of distressing symptoms in the
Additional Symptoms Dimension. Moreover, lastly, 14 participants were classified as having an absence of distressing symptoms in the Somatization and $\mathrm{Ob}-$ sessive-Compulsive Dimensions. The highest classification of severity reached by the participants in the study was "Extremely," which was experienced in the Somatization Dimension $(n=1)$ (See Table 4$)$.

Table 3

Beck Scales Results (BAI, BDI-II, BHS) and Mini-Mental Cognitive Functioning.

\begin{tabular}{|c|c|c|c|c|}
\hline & Score on BAI & $\begin{array}{c}\text { Score of } \\
\text { BDI- II }\end{array}$ & Score on BHS & $\begin{array}{l}\text { Mini- } \\
\text { Mental }\end{array}$ \\
\hline I & 0 (Minimal) & 0 (Minimal) & 11 (Moderate) & 29 (High) \\
\hline II & 6 (Minimal) & 1 (Minimal) & 9 (Moderate) & 30 (High) \\
\hline III & 1 (Minimal) & 0 (Minimal) & 10 (Moderate) & 27 (High) \\
\hline IV & 6 (Minimal) & 1 (Minimal) & 11 (Moderate) & 29 (High) \\
\hline $\mathrm{V}$ & 0 (Minimal) & 0 (Minimal) & 12 (Moderate) & 30 (high) \\
\hline VI & 9 (Minimal) & 17 (Mild) & 9 (Moderate) & 28 (High) \\
\hline VII & 7 (Minimal) & 5 (Minimal) & 11 (Moderate) & 30 (high) \\
\hline VIII & 2 (Minimal) & 6 (Minimal) & 12 (Moderate) & 30 (high) \\
\hline IX & 0 (Minimal) & 0 (Minimal) & 12 (Moderate) & 29 (High) \\
\hline$x$ & 1 (Minimal) & 2 (Minimal) & 11 (Moderate) & 28 (high) \\
\hline XI & 3 (Minimal) & 4 (Minimal) & 10 (Moderate) & 29 (High) \\
\hline XII & 0 (Minimal) & 4 (Minimal) & 14 (Moderate) & 30 (High) \\
\hline XIII & 2 (Minimal) & 3 (Minimal) & 11 (Moderate) & 29 (High) \\
\hline XIV & 1 (Minimal) & 2 (Minimal) & 11 (Moderate) & 29 (High) \\
\hline $\mathrm{XV}$ & 5 (Minimal) & 1 (Minimal) & 11 (moderate) & 30 (High) \\
\hline XVI & 9 (Minimal) & 8 (Minimal) & 12 (Moderate) & 26 (High) \\
\hline XVII & 7 (Minimal) & 5 (Minimal) & 11 (Moderate) & 28 (High) \\
\hline XVIII & 6 (Minimal) & 5 (Minimal) & 10 (Moderate) & 29 (High) \\
\hline XIX & 19 (Moderate) & 26 (Moderate) & 8 (Mild) & 29 (High) \\
\hline$X X$ & 8 (Minimal) & 15 (Mild) & 9 (Moderate) & 30 (High) \\
\hline XXI & 2 (Minimal) & 9 (Minimal) & 10 (Moderate) & 29 (High) \\
\hline XXII & 17 (Moderate) & 30 (Severe) & 11 (Moderate) & 27 (High) \\
\hline XXIII & 4 (Minimal) & 0 (Minimal) & 10 (Moderate) & 30 (High) \\
\hline XXIV & 10 (Mild) & 16 (Mild) & 7 (Mild) & 23 (Low) \\
\hline$X X V$ & 7 (Minimal) & 18 (Minimal) & 10 (Moderate) & 23 (Low) \\
\hline Mean & 5.28 & 7.12 & 10.52 & 28.44 \\
\hline$p$ & $p>.05$ & $p<.05$ & $p<.05$ & $p<.05$ \\
\hline
\end{tabular}


Table 4

Mean of Frequencies among SCL-90-R Dimensions.

\begin{tabular}{|c|c|c|c|c|c|c|c|c|c|c|}
\hline \multirow{3}{*}{$\begin{array}{l}\text { SCL-90-R } \\
\text { Dimen- } \\
\text { sions }\end{array}$} & \multicolumn{10}{|c|}{ Classification } \\
\hline & \multicolumn{2}{|c|}{$\begin{array}{c}\text { Not at } \\
\text { all }\end{array}$} & \multicolumn{2}{|c|}{$\begin{array}{c}\text { A Little } \\
\text { Bit }\end{array}$} & \multicolumn{2}{|c|}{$\begin{array}{l}\text { Moder- } \\
\text { ately }\end{array}$} & \multicolumn{2}{|c|}{$\begin{array}{c}\text { Quite } \\
\text { a Bit }\end{array}$} & \multicolumn{2}{|c|}{$\begin{array}{l}\text { Ex- } \\
\text { tremely }\end{array}$} \\
\hline & $f$ & $\%$ & $f$ & $\%$ & $f$ & $\%$ & $f$ & $\%$ & $f$ & $\%$ \\
\hline $\begin{array}{l}\text { Somatiza- } \\
\text { tion }\end{array}$ & 14 & 56 & 7 & 28 & 2 & 8 & 1 & 4 & 1 & 4 \\
\hline Obsessive & & & & & & & & & & \\
\hline $\begin{array}{l}\text { Compul- } \\
\text { sive }\end{array}$ & 14 & 56 & 6 & 24 & 3 & 12 & 2 & 8 & 0 & 0 \\
\hline $\begin{array}{l}\text { Interper- } \\
\text { sonal Sen- } \\
\text { sitivity }\end{array}$ & 17 & 68 & 6 & 24 & 1 & 4 & 1 & 4 & 0 & 0 \\
\hline Depression & 18 & 72 & 4 & 16 & 2 & 8 & 1 & 4 & 0 & 0 \\
\hline Anxiety & 20 & 80 & 4 & 16 & 1 & 4 & 0 & 0 & 0 & 0 \\
\hline Hostility & 20 & 80 & 4 & 16 & 1 & 4 & 0 & 0 & 0 & 0 \\
\hline $\begin{array}{l}\text { Phobic } \\
\text { Anxiety }\end{array}$ & 21 & 84 & 2 & 8 & 1 & 4 & 1 & 4 & 0 & 0 \\
\hline $\begin{array}{l}\text { Paranoid } \\
\text { Ideation }\end{array}$ & 17 & 68 & 6 & 24 & 2 & 8 & 0 & 0 & 0 & 0 \\
\hline $\begin{array}{l}\text { Psychoti- } \\
\text { cism }\end{array}$ & 21 & 84 & 3 & 12 & 1 & 4 & 0 & 0 & 0 & 0 \\
\hline $\begin{array}{l}\text { Additional } \\
\text { Symptoms }\end{array}$ & 16 & 64 & 5 & 20 & 2 & 8 & 1 & 4 & 1 & 4 \\
\hline $\begin{array}{l}\text { Global Se- } \\
\text { verity In- } \\
\text { dex }\end{array}$ & 17 & 68 & 5 & 20 & 2 & 8 & 1 & 4 & 0 & 0 \\
\hline
\end{tabular}

The norms followed in interpreting the SCL-90-R scores were the Non-Patient Female normative sample. Each participant's raw score in each dimension was transformed into a T score. The T score is calculated with the following formula: $\mathrm{T}=50+10(\mathrm{z})$. This translates to a mean of 50 and a standard deviation of 10. A range of plus or minus 5 is a standard deviation represented by the $\mathrm{T}$ distribution from 0 to 100 . Thus, a T score of 60 places the participant in the $84 \%$ centile of the normative population, which indicates distressing symptomatology compared to the norm $(+1$ $\mathrm{SD})$.

In terms of raw scoring, the following participants scored above a T Score of 60: 10 participants scored higher than .72 showing distressing symptomatology in the Somatization Dimension. Eleven participants scored more than .76, showing distressing symptomatology in the Obsessive-Compulsive Dimension. Eight participants scored higher than .64, showing distressing symptomatology in the Interpersonal Sensitivity Dimension. Four participants scored higher than .76, showing distressing symptomatology in the Depression Dimension. Two participants scored higher than .72, showing distressing symptomatology in the Anxiety Dimension. One participant scored higher than .64 showing distressing symptomatology in the Hostility Dimension. Five participants scored higher than .33, showing distressing symptomatology in the Phobic Anxiety Dimension. Eight participants scored higher than .64, showing distressing symptomatology in the Paranoid Ideation Dimension. Five participants scored higher than .28, showing distressing symptomatology in the Psychoticism Dimension. Seven participants scored higher than .56, showing distressing symptomatology in the Global Severity Index (See Table 5).

An ANOVA analysis was carried out to test significance levels of the subscales of the SCL-90-R Dimensions. In the following Dimensions significant statistical differences were found: Somatization Dimension $(F=3.20, p<.05)$, Obsessive Compulsive Dimension $(F=3.78, p<.05)$, Depression Dimension $(F=3.02, \mathrm{p}<$ $.05)$, Anxiety Dimension $(F=3.64, p<.05)$, Hostility Dimension $(F=7.03, p<.05)$, Psychoticism Dimension $(F=3.48, p<.05)$ and Global Index Severity $(F=7.38$, $p<.05$ ) (See Table 6).

\section{DISCUSSION}

The study's results were from a battery of administered instruments (i.e., BAI, BDI-II, BHS, SCL-90R, and Mini-Mental Folstein) intending to compare and establish a relationship in cognitive health (or decline), and psychological and emotional wellbeing or distress. The scores obtained allow for a general discussion on this particular sample of Puerto Rican Catholic Nuns in terms of evaluating whether anxiety, depressive, and hopelessness symptoms are present, as well as possible psychopathology.

First off, the results obtained from the Beck Anxiety Inventory (BAI) suggest low levels or a minimum presence of distressing symptoms. However, four participants showed mild symptoms related to anxiety, curious and exciting enough, and reported mild and moderate symptoms in the Beck Depression 
Table 5

Raw Scores in Dimensions of SCL-90-R.

\begin{tabular}{|c|c|c|c|c|c|c|c|c|c|c|c|}
\hline & GSI & SOM & OC & IS & DEP & ANX & HOS & PHOB & PAR & PSY & $\mathrm{ADL}$ \\
\hline I & .12 & .00 & .00 & .67 & .54 & .00 & .17 & .00 & .00 & .00 & .00 \\
\hline II & .42 & .75 & .60 & .50 & .17 & .30 & .40 & .00 & .00 & .11 & .57 \\
\hline III & .18 & .08 & .40 & .64 & .17 & .10 & .00 & .00 & .00 & .00 & .29 \\
\hline IV & .30 & .83 & .60 & .44 & .08 & .10 & .00 & .00 & .00 & .00 & .43 \\
\hline $\mathrm{V}$ & .21 & .17 & .40 & .44 & .08 & .10 & .17 & .14 & .50 & .20 & .00 \\
\hline VI & .80 & 1.50 & 1.60 & 1.11 & .46 & .40 & .33 & .57 & .33 & .20 & 1.1 \\
\hline VII & .50 & 1.42 & .30 & .44 & .23 & .10 & .50 & .00 & .67 & .30 & 1.0 \\
\hline VIII & .33 & .33 & .90 & .22 & .38 & .00 & .17 & .28 & .67 & .00 & .43 \\
\hline IX & .21 & .17 & .40 & .00 & .23 & .40 & .33 & .14 & .17 & .10 & .14 \\
\hline$x$ & .47 & .42 & .80 & 1.00 & .38 & .20 & .33 & .28 & .50 & .20 & .57 \\
\hline XI & .11 & .33 & .20 & .00 & .08 & .20 & .00 & .00 & .00 & .00 & .14 \\
\hline XII & .39 & .25 & 1.10 & .44 & .42 & .30 & .00 & .43 & .50 & .00 & .29 \\
\hline XIII & .11 & .00 & .00 & .33 & .23 & .00 & .00 & .00 & .33 & .00 & .29 \\
\hline XIV & .10 & .42 & .10 & .00 & .00 & .00 & .00 & .00 & .17 & .10 & .14 \\
\hline XV & .40 & .18 & .40 & .78 & .31 & .20 & .33 & .57 & .67 & .20 & .71 \\
\hline XVI & .38 & .67 & .50 & .00 & .25 & .20 & .00 & .29 & .50 & .44 & $1.0 \mathrm{C}$ \\
\hline XVII & .29 & .67 & .60 & .00 & .31 & .20 & .17 & .00 & .33 & .10 & .27 \\
\hline XVIII & .61 & 1.17 & .80 & .44 & .62 & .20 & .67 & .29 & .67 & .10 & 1.1 \\
\hline XIX & 1.23 & 2.20 & 1.80 & 1.44 & 1.23 & 1.30 & .17 & .14 & 1.33 & .70 & 1.71 \\
\hline$x X$ & .73 & .50 & 1.20 & 1.22 & .77 & .70 & .50 & .58 & 1.00 & .30 & .57 \\
\hline XXI & .54 & 1.42 & 1.10 & .22 & .69 & .20 & .33 & .14 & .17 & .00 & .43 \\
\hline XXII & .71 & 1.25 & 1.00 & .33 & .62 & .40 & .33 & .29 & .33 & .20 & 2.29 \\
\hline XXIII & .18 & .58 & .10 & .55 & .08 & .10 & .00 & .00 & .17 & .00 & .00 \\
\hline XXIV & .63 & 1.00 & 1.00 & 1.00 & .85 & .20 & .33 & .00 & 1.00 & .20 & .43 \\
\hline$X X V$ & 1.06 & 1.50 & 1.60 & .22 & .77 & 1.40 & .50 & .71 & .67 & 1.22 & .57 \\
\hline
\end{tabular}

Inventory (BDI-II) and the Beck Hopelessness invent-tory (BHS). These results suggest that when anxiety, depression, and hopelessness collide, those particular subjects portray the need for possible psychological intervention to explore the nature of these profound reports.

Within the framework of symptoms related to anxiety, it is characterized by an early fear of an event that has not yet manifested-keeping in mind that the religious lifestyle of the nuns is often characterized by an atmosphere of tranquility, and where contemplation is one of the frequent practices held by members of these religious congregations. This type of activity reduces stress on somatization individuals and the use of prayer, perhaps viewed as an oasis to discharge or channel their feelings. Also, some of the physical manifestations reported did belong to many of their medical conditions could be confused with the outlet of anxiety symptoms. Many of the nuns that participated made questions on the items present in this inventory. Nuns made the distinction between the effects of aging and their particular health conditions and anxiety symptoms. These distinctions were also made when answering the Somatization subscale in the SCL-90R.

Secondly, regarding the Beck Depression Inventory (BDI-II), which is related to the negative cognitions the individual has about the world, the future, and itself, it demonstrates that the vast majority of participants showed minimal symptoms of depression. However, one should consider that three participants reported mild symptoms, and one reported moderate symptoms. These findings are consistent with the statements of the Beck Hopelessness Inventory (BHS), which involves more towards future perspective and with the subscale of depression in the SCL-90R. Regarding the Beck Hopelessness Inventory (BHS), it measures the need for affection and well-being in terms of the future. This psychological construct exists as an asymptomatic cognitive style consisting of a negative sense of self about the future. Participating nuns, in their majority, counting 23, did report moderate hopelessness.

This data could be interpreted as a mindset that comes about consequentially to the liberal socio-political movements that are now mainstream in Puerto Rican society. Also, the vocation of a Catholic nun that has spread throughout the world for hundreds of years is not as popular in Puerto Rican society as it once was. This could be due to world globalization, access to information and education, and the women have fought for their rights to equal those of men and transcend the traditional social roles. Literature suggests that women in the past were usually drawn to become nuns "to escape marriage, receive an education, and live in a community of women" (Curb, 1985). Because of the limitation's women face in education, this was a means to an end for women who wanted a formal education and not have to comply demands of a society of marrying a man and be a simple housewife. 
Table 6

Mean T Scores and ANOVA significance test for sub-scales in SCL-90R Dimensions.

\begin{tabular}{|c|c|c|c|c|c|}
\hline $\begin{array}{l}\text { SCL-90-R } \\
\text { Dimen- } \\
\text { sions }\end{array}$ & & $\begin{array}{c}\text { Range T } \\
\text { Scores }\end{array}$ & $\begin{array}{c}\text { T Scores } \\
\text { Mean }\end{array}$ & $\mathrm{F}$ & $p$ \\
\hline $\begin{array}{l}\text { Somatiza- } \\
\text { tion }\end{array}$ & $\begin{array}{l}\min \\
\max \end{array}$ & $\begin{array}{l}35 \\
76\end{array}$ & 55 & 3.201 & .050 \\
\hline $\begin{array}{l}\text { Obsessive } \\
\text { Compul- } \\
\text { sive }\end{array}$ & $\begin{array}{l}\min \\
\max \end{array}$ & $\begin{array}{l}37 \\
70\end{array}$ & 56 & 3.782 & 0.031 \\
\hline $\begin{array}{l}\text { Interper- } \\
\text { sonal Sen- } \\
\text { sitivity }\end{array}$ & $\begin{array}{l}\min \\
\max \end{array}$ & $\begin{array}{l}39 \\
69\end{array}$ & 54 & 1.750 & .214 \\
\hline $\begin{array}{l}\text { Depres- } \\
\text { sion }\end{array}$ & $\begin{array}{l}\min \\
\max \end{array}$ & $\begin{array}{l}34 \\
63\end{array}$ & 51 & 3.025 & .058 \\
\hline Anxiety & $\begin{array}{l}\min \\
\max \end{array}$ & $\begin{array}{l}37 \\
68\end{array}$ & 49 & 3.647 & .035 \\
\hline Hostility & $\begin{array}{l}\min \\
\max \end{array}$ & $\begin{array}{l}40 \\
60\end{array}$ & 49 & 7.032 & .004 \\
\hline $\begin{array}{l}\text { Phobic } \\
\text { Anxiety }\end{array}$ & $\begin{array}{l}\min \\
\max \end{array}$ & $\begin{array}{l}44 \\
65\end{array}$ & 52 & 2.659 & .082 \\
\hline $\begin{array}{l}\text { Paranoid } \\
\text { Ideation }\end{array}$ & $\begin{array}{l}\min \\
\max \end{array}$ & $\begin{array}{l}41 \\
67\end{array}$ & 53 & 1.121 & .455 \\
\hline $\begin{array}{l}\text { Psychoti- } \\
\text { cism }\end{array}$ & $\begin{array}{l}\min \\
\max \end{array}$ & $\begin{array}{l}44 \\
73\end{array}$ & 53 & 3.842 & .040 \\
\hline $\begin{array}{l}\text { Global Se- } \\
\text { verity In- } \\
\quad \text { dex }\end{array}$ & $\begin{array}{l}\min \\
\max \end{array}$ & $\begin{array}{l}41 \\
68\end{array}$ & 54 & 7.381 & .000 \\
\hline
\end{tabular}

Since the roles that these women once performed are being carried out less, many of these nuns prepare themselves through education and choosing to live an apostolic lifestyle over cloister life. Historical examples related to these ways of life include the famous Sor Juana Inés de la Cruz, nun, scholar, and poet that joined the convent to educate herself and within the monastery, defend women's right to study in the seventeenth century-choosing the apostolic life. The beloved Mother Theresa, a devout catholic missionary nun who traveled the world, dedicating her life to helping the poor in the twentieth century.

However, future studies on hopefulness and hopelessness of nuns on their future way of life in Puerto Rico could benefit from the present data to provide a more detailed experiential account of the experience of contemporary nuns. Also, hopelessness could be seen as a manifestation of Catholic Stoicism, given the belief nuns have regarding their function as servants of God, which transcends the personal sense of happiness or sadness, through sacrifice. As a result, the separation of church and state, the economic crisis and the rise of crime, among other social factors still affect major institutions like church and even the most hopeful individuals, such as nuns.

Results on the Mini-Mental State Examination (MMSE) Folstein Version, indicate high cognitive functioning among 23 participating nuns. This test covers essential functioning areas such as orientation, attention, calculation, recall, and language. The data on the participants' cognitive function levels serves as an indicator of the mental process underlying the participants' behavior. The scores indicate that the participants exhibit a healthy cognitive profile that may result from an active and ritualized lifestyle that emphasizes detail, repetition, and order. We can also discard that the nuns partake in high risk, excessive or self-destructive behavior that may result in long term cognitive impairment (i.e., consumption of drugs, or psychoactive compounds that are not prescribed).

In terms of the SCL-90-R results, physical discomfort related to bodily dysfunction was measured in the Somatization Dimension. The nun's population mean age is around 60 years old. Therefore, it is expected that they face some physiological problems. These discomforts may come as a result of certain age-related health conditions, including arthritis, osteoporosis, heart conditions, blood pressure, and back conditions. Another critical dimension is the $\mathrm{Ob}-$ sessive-Compulsive symptoms subscale, which can be attributed to the structured way of life that the nuns have adopted. Also, this measure focuses on impulses, thoughts, and actions, some that come with the need to maintain order and do things a certain way, such as cleanliness and a neat environment. Comparing the depression measure with the Beck's 
Depression Inventory scores, feelings of loneliness, worrying, low energy, and loss of interest are common among this population. Again, more than half reported minimal symptomatology, but it is evident that there are some indicators present. When comparing anxiety measures with the Beck Anxiety Inventory scores, one observes that many of these questions could be somatic, and the common side effects of aging are not severe enough to be considered dysfunctional.

The Hostility concept mainly covers the feeling of irritation and perhaps managing momentary anger over the clash of popular and religious beliefs. Most of the nuns that participated are active in the apostolic way of life, in the way they interact continuously with different kinds of people, and the way they educate children in school settings. Many of these schools teach religion in their curriculum and have a Christian base. It can be quite challenging as the children turn into adolescents to keep such a structured regime, but for the nuns, the challenge lies in staying sane and adaptive in the modern world. In the aspect of measuring psychoticism, one must keep in mind that nuns have a direct connection with God. Nuns pray daily, and their way of life is open to spiritual intervention, under their belief. Under the psychoticism criteria that make up the items of this subscale, behavior that is considered maladaptive and symptomatic of psychopathology could be contemplated as an adaptive way of life under the consecrated lifestyle of the participants. For example, "hearing voices" might be considered psychopathological in a clinical setting but "hearing angelic voices or hearing God's calling" is an expression that makes sense and where some of the nuns can feel identified because they believe that these voices come from actual entities that call to them to be chosen to partake this way of life.

\section{REFERENCIAS}

Bird, H., Canino, G., Rubio Stipec, M., \& Shrout, P. (1987). Use of the Mini-mental State Examination in a Probability Sample of a Hispanic Population. The Journal of Nervous and Mental Disease, 175(12), 731-737. https://doi.org/10.1097/00005053198712000-00005

Beck, A. T., Weissman, A., Lester, D., \& Trexler, L. (1974). The measurement of pessimism: The Hopelessness Scale. Journal of Consulting and Clinical Psychology, 42(6), 861-865. https://doi.org/10.1037/h0037562

\section{Limitations and Future Research}

This is a pioneer study among the catholic nun population residing in Puerto Rico. As the first one to be conducted, the results do indicate a need for prevention and counseling on mental health for these women. Hopeful of setting the stage for future research, which may include a more significant sample, it would also help make distinctions among cloistered and apostolic nuns, to compare and contrast and have more specificity in the results. A mixed methodology, integrating qualitative interviewing, would undoubtedly bring dimensionality and life to their storytelling. This population in its majority is of the elderly, whose stories are unheard and left untold. This approach would deepen the knowledge known on their particular experiences and perhaps have an idea of how times have changed in their way of life over the years.

\section{CONCLUSIONS}

Nuns contribute to society and are still present daily as productive human beings, albeit Puerto Rico they are not commonly seen as they used to be. Nevertheless, they are still present in schools, hospitals, communities, and churches. Given that Catholic nuns have been mainly under-researched in the social sciences and almost no peer-reviewed qualitative data exists on Puerto Rican Nun perceptions of convent life and society in general, it is difficult to generalize about the data obtained. This is a present limitation, given the pioneering nature of the study. Nuns have played an essential part in the Catholic Church's trajectory worldwide, as a religion and socially organizing institution, so in effect, it makes them a relevant group worthy of scientific study.

Funding: This research received no external funding.

Conflict of Interest: The authors declare no conflict of interest.

Beck, A.T., \& Steer, R.A. (1993). Beck Anxiety Inventory Manual. Pearson.

Beck, A.T. \& Steer, R.A. (1993). Beck Hopelessness Scale. The psychological Corporation.

Beck, A.T., Steer, R.A. \& Brown, G.K. (1996). BDI-II Manual. Pearson.

Brock, M. (2003). The Nun as called by God: Psychological implications 
in a sample of nuns in Australia/New Zealand. The international Journal of Religion and Spirituality in Society.

Broderick, R. C. (1976). The Catholic Encyclopedia. Thomas Nelson Inc. Publishers.

Campos Velazquez, E. (1997). Validez de la Prueba de Cernimiento Psicogeriatrico Nogal para Demencias en Puerto Rico. Centro Caribeño de Estudios Postgraduados.

Cardinal, L. J. (1963). The Nun in the World (Religious and Apostolate). The Newman Press.

CLAR. (1973). La vida según el espíritu en las comunidades religiosas de América Latina. Confederación Latinoamericana de Religiosos.

Curb, R. \& Manahan, N. (1985). Lesbian nuns: Breaking silence. The Naiad Press Inc.

Derogatis, L.R. (1997). Symptom Checklist-90-Revisited (tm) (SCL-90$\mathrm{R})$.

Galán, L. (2001). El Vaticano reconoce que cientos de monjas han sido violadas por misioneros. El País. http://elpais.com/diario/2001/03/21/sociedad/985129201_850215.html

Hernández-Sampieri, R., Fernández-Collado, C., \& Baptista-Lucio, P. (2006). Metodología de la Investigación. Mc Graw Hill.

Kuhns, E. (2003). The Habit: A history of the clothing of Catholic nuns. Doubleday.
Kurlowicz, L., \& Wallace, M. (1999). The Mini Mental State Examination (MMSE). Journal of Gerontological Nursing, 25(5), 8-9. https://doi.org/10.3928/0098-9134-19990501-08

Rivera, G. M. (1998). La libertad femenina en las instituciones religiosas medievales. En Anuario de estudios medievales. Instituto de Historia Medieval de España.

Rodríguez-Reynaldo, M. (2000). Estudio de las características psicométricas del Inventario de Ansiedad Beck (versión al español) en una muestra puertorriqueña de edad avanzada. (Disertación Doctoral). Universidad Carlos Albizu, San Juan, Puerto Rico.

Rosado-Medina, J. (2012). Estudio sobre los factores internos de resiliencia en una muestra de centenarios puertorriqueños. (Disertación Doctoral). Universidad Carlos Albizu, San Juan, Puerto Rico.

Sans, E. (1989). Espacios de religiosidad de las mujeres dentro de una orden militar. In A. Muñoz (Ed.), Las mujeres en el cristianismo medieval (pp. 183-200). Al-Mudayna.

Smith, B. (2003, May 4). The Survivor's Network of Those Abused by Priests. [Web Log post] www.snapnetwork.com

Vera, R. (2003) El "Ya Basta" de las monjas: Exponen religiosas sus demandas al Vaticano, exigen crear un ombusman religioso. El Norte.

http://hemeroteca.proceso.com.mx/?page_id=278958\&a51dc26366d99bb5fa29cea474 $7565 \mathrm{fec}=190052 \& \mathrm{rl}=\mathrm{wh}$

\section{Obra bajo licencia de Creative Commons Atribución 4.0 Internacional (CC BY 4.0).} (C) 2020 Autores. 